\title{
Editorial
}

\section{Beach Nourishment: A 21st Century Review}

\author{
Luis J. Moreno ${ }^{1, *}$ and Juan J. Muñoz-Perez ${ }^{2, *(D)}$ \\ 1 Department of Civil Engineering: Hydraulics, Energy and Environment, Technical University of Madrid, \\ Prof. Aranguren 3, 28040 Madrid, Spain \\ 2 CASEM, University of Cadiz, Rio San Pedro s/n, 11510 Puerto Real, Spain \\ * Correspondence: luisjuan.moreno@upm.es (L.J.M.); juanjose.munoz@uca.es (J.J.M.-P.)
}

Citation: Moreno, L.J.; Muñoz-Perez,

J.J. Beach Nourishment: A 21st

Century Review. J. Mar. Sci. Eng.

2021, 9, 499. https://doi.org/

$10.3390 /$ jmse9050499

Received: 21 April 2021

Accepted: 29 April 2021

Published: 5 May 2021

Publisher's Note: MDPI stays neutral with regard to jurisdictional claims in published maps and institutional affiliations.

Copyright: (c) 2021 by the authors. Licensee MDPI, Basel, Switzerland. This article is an open access article distributed under the terms and conditions of the Creative Commons Attribution (CC BY) license (https:// creativecommons.org/licenses/by/ $4.0 /)$.
Long-term erosion is experienced by most of the coastlines worldwide, and it is usually attributed not only to sea level rise but also to the retention of sand in dams, the occupation of dry beaches by urbanized areas, the disturbance of the natural patterns of longshore drift, the mining of sand as building material for construction, and so on. Beach nourishment has evolved as the favored erosion-mitigation strategy in many areas of the world. The increasing number of people living on the coast, the safety of those people, and the high values of coastal property [1] are all factors that have made beach nourishment a cost-effective strategy for managing erosion in many locations. However, a new scenario of sand scarcity and environmental care has arisen in recent decades [2]. There have been a number of different and interesting cases of various aspects of beach nourishment in the last years. The purpose of this Special Issue has been to publish the different experiences and research related to this topic.

After a careful review process, nine papers were included. Their thematic contributions include the use of field methods such as the use of remotely piloted aircraft systems (RPAS) or un-manned aerial vehicles (UAV) for faster and automated mapping of the coastal area or the acquisition of geomagnetic data in marine environments; the use of multi-approach methodologies to assess the interaction between coastal structures and beaches and in particular of submerged pipelines; the need to adopt a plan for the optimal use of limited resources of available sediment from a regional perspective and the assessment of the effectiveness of beach nourishments; the understanding of the role of submerged geological control of beach profiles together with the implementation of innovative beach nourishment strategies while facing the non-trivial challenge of visualizing and communicating mesoscale modeling assumptions, uncertainties and outcomes to both coastal specialists and decision makers; and the influence of sea-level rise and erosion on diminution of beach habitats.

The contributions are commented upon in order of appearance in this Special Issue. Although an effort has been made to compile contributions that cover an update in the state-of-the-art of innovative techniques in beach nourishment, by no means should they be limited to the topics presented hereby.

To begin with, the size and great dynamism of coastal systems require faster and more automated mapping methods, such as the use of a remotely piloted aircraft system (RPAS) or unmanned aerial vehicle (UAV). However, the main problem for surveying using lowaltitude digital photogrammetry in beach areas is their visual homogeneity. Obviously, the fewer the homologous points defined by the software, the lower the accuracy. Contreras-deVillar et al. [3] have addressed the error performed in photogrammetric techniques, such as flight height, flight time, percentage of frame overlap (side and forward), and the number of ground control points (GCPs). Among their conclusions, it should be highlighted that the error for noon flights is almost double that for early morning flights. Moreover, a minimum value of 7 GCP per hectare should be taken into account when designing a beach leveling campaign using RPAS. 
Coastal areas are usually very impacted because of demographic and industrial pressure, which leads to an interaction between anthropic infrastructures and littoral dynamics. One of the public works that can most influence the sediment transport is a submerged pipeline. Lersundi-Kanpistegi et al. [4] studied the extension of the wastewater pipeline in Vigo (Northwest Spain) crossing the most important urban beach of the city by using a multi-tool strategy based on high resolution bathymetry data, seabed physical characterization, a grain size study of the superficial sediment, and a numerical simulation of the tide, wave climate, and sediment transport in low and high energy conditions using the open source Delft3D software. The results indicate characteristics that the design must follow in order to ensure that the future structure would not alter the global sediment dynamics of the beach. The multi-approach methodology presented can be applied to other studies of the interaction between coastal structures and beaches.

Beach nourishment is generally seen as the preferred means of rectifying coastal erosion, due to its low environmental impact and natural evolution. Martell et al. [5] present a study regarding the effectiveness of beach nourishments in Cancun (Mexico), but its conclusions regarding the erosion tendency directly linked to the incidence of extreme hydrodynamic conditions and the scarcity of natural sediment sources can be applied to beaches with similar characteristics in any other area. Furthermore, the need for improving long term predictions of the wave climate under global warming scenarios must be highlighted.

Submerged geological control of beach profiles, e.g., through the existence of reef flats or submerged sills, is a topic that has been widely studied over the last years. Moreover, fringing reefs have significant impacts on beach dynamics, yet there is little research on how they should be considered in beach nourishment design, monitoring, and conservation work. Thus, the behavior and characteristics of nourishment projects at two reef protected beaches, in Hawaii (USA) and in Cadiz (Spain), are compared [6] to provide transferable information for future nourishment projects and monitoring in this type of environment. Several differences were detected related to the nourishment cost, distance to the borrow site, post-nourishment monitoring frequency and assessment of accuracy, measurement of the beach volume increase after nourishment, etc.

Innovative beach nourishment strategies have been developed in the last decade, driven by the increased worldwide interest in environmentally friendly coastal protection measures. In this context, the massive nourishment project of the Netherlands (known as Sand Engine [7]) has been hailed as a successful means of beach protection. Adapting this idea, a very small and bell-shaped Sand Engine was designed to protect the beachfront at a tourist resort near Puerto Morelos, Mexico [8]. This micro Sand Engine is seen as a sustainable and eco-friendly coastal protection measure, especially applicable when large nourishment projects are not viable. Maintenance work for this type of nourishment is cost- and time-effective, and any negative impacts on sensitive ecosystems nearby can be detected and controlled quickly.

Coastal geomorphologists and engineers worldwide are increasingly facing the nontrivial challenge of visualizing and communicating mesoscale modeling assumptions, uncertainties and outcomes to both coastal specialists and decision makers. Payo et al. [9] show how the risk of simulation model outcomes can be minimized by using the Coastal Modeling Environment (CoastalME). CoastalME is a modeling framework for coastal mesoscale morphological modeling that can achieve close linkages between the scientific model abstractions and the 3D representation of topographic and bathymetric surfaces. A transparent methodology to merge the required variety of data types and formats into a 3D-thickness model is presented through the case study of Happisburgh (eastern England, UK). Finally, some of the barriers to the adoption of this methodology are analyzed.

Sometimes, the limited resources of available sediment make it necessary to adopt a plan for their optimal use from a regional perspective. This is the case presented by Pranzini et al. [10], who present a study carried out to support the Region of Tuscany Coastal Sediment Management Plan along the $215 \mathrm{~km}$-long continental sandy coast of this 
Italian region. Sand stability and color compatibility were determined in order to assess the possibility of using the available sediment in accreting sectors to nourish the beach in eroding areas. This kind of study is of great interest for the proposal of sound management actions to counteract the increasing erosion processes linked to climate change phenomena and human effects on rivers and coastal systems.

A method for the acquisition of geomagnetic data in marine environments, developed by the Oceanographic and Hydrographic Research Center of Colombia, is presented by Oviedo et al. [11]. Leaving sub-bottom profiling and side-scan sonar techniques aside, the most representative uses of the geomagnetic method are the location of pipelines and metal plates, detection of buried ordnance, identification of sites of archaeological interest, and the characterization of geological structures. To test the method, a grid of geomagnetic data was surveyed in an area close to the island of San Andrés (Northwest Colombian maritime territory) and compared with survey data obtained from National Oceanic and Atmospheric Administration (NOAA) magnetic data. Despite the long time interval between the two surveys, almost 50 years, no significant differences were observed in terms of the analyzed variables.

Finally, the influence of sea-level rise and erosion (along with shoreline hardening and reduced sediment inputs) on diminution of beach habitats is shown by Martin et al. [12]. Their study shows that increasing sandy beach habitat can be beneficial to wildlife, but the method of placement, timing of the project, and fate of the beach afterward can modulate or prevent beneficial effects. Frequent repetition of sand placement may accumulate impacts without allowing sufficient time for the ecosystem to recover.

Closing this editorial, the guest editors consider that this Special Issue will provide benefits to technicians, engineers, researchers and managers in the area of beach nourishment.

Author Contributions: L.J.M. and J.J.M.-P. wrote and reviewed this editorial, and both authors have agreed to the published version of the manuscript. All authors have read and agreed to the published version of the manuscript.

Funding: This research received no external funding.

Acknowledgments: The Guest Editors wish to express their deepest appreciation to the authors for their cooperation, to the anonymous reviewers for their valuable comments, and to the Editor-inChief for the valuable comments, as well as to Esme Wang for her guidance, continuous support, and constructive advice throughout the publication process.

Conflicts of Interest: The authors declare no conflict of interest.

\section{References}

1. Houston, J.R. The economic value of America's beaches-A 2018 update. Shore Beach 2018, 86, 3-13.

2. Herrera, A.; Gomez-Pina, G.; Fages, L.; De La Casa, A.; Munoz-Perez, J.J. Environmental Impact of Beach Nourishment: A Case Study of the Rio San Pedro Beach (SW Spain). Open Oceanogr. J. 2010, 4, 32-41. [CrossRef]

3. Contreras-De-Villar, F.; García, F.J.; Muñoz-Perez, J.J.; Contreras-De-Villar, A.; Ruiz-Ortiz, V.; Lopez, P.; Garcia-López, S.; Jigena, B. Beach Leveling Using a Remotely Piloted Aircraft System (RPAS): Problems and Solutions. J. Mar. Sci. Eng. 2020, 9, 19. [CrossRef]

4. Bernabeu, A.M.; Lersundi-Kanpistegi, A.; Rey, D.; Díaz, R. Multidata Study to Evaluate the Impact of Submarine Outfall in a Beach Sedimentary Dynamic: The Case of Samil Beach (Galicia, Spain). J. Mar. Sci. Eng. 2020, 8, 461. [CrossRef]

5. Martell, R.; Mendoza, E.; Mariño-Tapia, I.; Odériz, I.; Silva, R. How Effective Were the Beach Nourishments at Cancun? J. Mar. Sci. Eng. 2020, 8, 388. [CrossRef]

6. Muñoz-Perez, J.J.; Gallop, S.L.; Moreno, L.J. A Comparison of Beach Nourishment Methodology and Performance at Two Fringing Reef Beaches in Waikiki (Hawaii, USA) and Cadiz (SW Spain). J. Mar. Sci. Eng. 2020, 8, 266. [CrossRef]

7. Stive, M.J.; De Schipper, M.A.; Luijendijk, A.P.; Aarninkhof, S.G.; Van Gelder-Maas, C.; Vries, J.S.V.T.D.; De Vries, S.; Henriquez, M.; Marx, S.; Ranasinghe, R. A New Alternative to Saving Our Beaches from Sea-Level Rise: The Sand Engine. J. Coast. Res. 2013, 290, 1001-1008. [CrossRef]

8. Escudero, M.; Mendoza, E.; Silva, R. Micro Sand Engine Beach Stabilization Strategy at Puerto Morelos, Mexico. J. Mar. Sci. Eng. 2020, 8, 247. [CrossRef]

9. Payo, A.; French, J.R.; Sutherland, J.; Ellis, M.A.; Walkden, M. Communicating Simulation Outputs of Mesoscale Coastal Evolution to Specialist and Non-Specialist Audiences. J. Mar. Sci. Eng. 2020, 8, 235. [CrossRef] 
10. Pranzini, E.; Cinelli, I.; Cipriani, L.E.; Anfuso, G. An Integrated Coastal Sediment Management Plan: The Example of the Tuscany Region (Italy). J. Mar. Sci. Eng. 2020, 8, 33. [CrossRef]

11. Prada, K.O.; Antelo, B.J.; Murillo, N.O.; Cózar, J.R.; Contreras-De-Villar, F.; Muñoz-Pérez, J.J. A New Method for the Collection of Marine Geomagnetic Information: Survey Application in the Colombian Caribbean. J. Mar. Sci. Eng. 2020, 9, 10. [CrossRef]

12. Martin, K.L.M.; Adams, L.C. Effects of Repeated Sand Replenishment Projects on Runs of a Beach-Spawning Fish, the California Grunion. J. Mar. Sci. Eng. 2020, 8, 178. [CrossRef] 